\title{
A Study on the Use of Songs to Improve Students' Pronunciation and Listening Skill
}

Fergina Lengkoan

\begin{abstract}
The aims of this research are to describe how is the process of teaching listening and pronunciation by using songs and to find out if the use of songs can help improve students' pronunciation and listening skill at English education department. This study is a classroom action research. The population of this research was students of the second semester at English Education Department. The sample of this research was class B in Intermediate Listening subject and the total students involved in this research were of 23 students. The instruments of this research were tests, in the form of oral test and written test, observation sheetsand documents. The implementation of this research was conducted in two cycles, every cycle consisted with the steps of planning, acting, observing, and reflecting. The findings in the analysis show that the action research was successfull, because the results of quantitative data obtained for the first cycle was $39.3 \%$ of the total number of students declared not succeeded and the second cycle $86.9 \%$ of the total number of students declared successful and the results of qualitative data through observation sheets and documents showed that the use of songs can improve students' pronunciation and listening skill. There is an increase in student learning outcomes of intermediate listening subjects after using the songs in teaching and learning activities. Based on the findings it is concluded that the use of songs could improve students' pronunciation and listening skill. Furthermore the use of songs is effective as a media to improve students' pronunciation and listening skill. Thus this research may suggest that the use of songs should be used routinely in each learning activity because in the activity the students would be able to comprehend what they learn. It is recommended, the use of songs which are simple, enjoyable, pleasurable, comfortable, and easy to learn may help students' learning.
\end{abstract}

Key Words: Songs, English Foreign Language, Pronunciation, and Listening

\section{INTRODUCTION}

Language is foremost a means of communication, and communication almost always takes place within some sort of social context. This is why effective communication requires an understanding and recognition of the connections between a language and the people who use it. These connections are complex: 
for example, they tell you when to use slang with a friend or formal language with a boss, how to judge a candidate's campaign speeches, and whether to abbreviate an email. All of these acts require knowledge of the language, as well as the cultural and social forces acting on that language.

In learning English, there are two main aspects that need to be learned, language skills and language components. Language skills consist of listening, speaking, reading, and writing, and language components consist of vocabulary, structure and pronunciation. Learners with good pronunciation in English are more likely to be understood even if they make errors in other areas, whereas learners whose pronunciation is difficult to understand will not be understood, even if their grammar is perfect. We also often judge people by the way they speak, and so learners with poor pronunciation may be judged as incompetent, uneducated or lacking in knowledge, even though listeners are only reacting to their pronunciation. Yet many adult learners find pronunciation one of the most difficult aspects of English to acquire, and need explicit help from the teacher (Morley 1994; Fraser 2000). Surveys of student needs consistently show that our learners feel the need for pronunciation work in class (eg Willing 1989). Thus some sort of pronunciation work in class is essential.

There is one majorreason for it: poor listening habits. We acquire most of these habits through daily casual conversation where habits of critical and comprehensive listening aren't required. If we're constantly critical or if we attempt to retain everything we hear, we're undertaking the impossible. On the other hand, if we understand that effective listening is acquired and not inherited, we may seek to acquire certain specific techniques that offer improvement. There are no quick and easy answers but the following techniques may get you started.

Human beings can communicate with each other. We are able to exchange knowledge, beliefs, opinions, wishes, threats, commands, thanks, promises, declarations, feelings - only our imagination sets limits. We can laugh to express amusement, happiness, or disrespect, we can smile to express amusement, pleasure, approval, or bitter feelings, we can shriek to express anger, excitement, or fear, we can clench our fists to express determination, anger or a threat, we can 
raise our eye brows to express surprise or disapproval, and so on, but our system of communication before anything else is language.

Most non native speakers of English have difficulties in pronouncing certain English words. It also happens to Indonesian people. It is because, there are some phonemes in English do not occur in Indonesian or local language. Another reason is English pronunciation is different from Indonesian pronunciation. Indonesian pronunciation, one letter is represented by one sound, for the example "aku” (a/-k/-u) but in English “than” (ðәn).

Learning English pronunciation rules will help you improve your listening. When pronouncing words incorrectly, you will find many difficulties in listening comprehension. However, the words and sentences you have listened are very familiar to you. Understand how native English speakers speak is the golden key to listen English better. Therefore, you should focus on pronunciation, especially stress, rhythm, connected speech and intonation. The easiest and most effective way to learn how to pronounce words correctly is to listen to native-speakers, and many people think that pronunciation is all about speaking. But in fact, learning the rules of English pronunciation allows students to understand native speakers better, and based on my own experience I know that the power of music in this case songs, and I am aware of what it does to my mind and memory, yet I do not think I should expect the same effect on everyone. Therefore, I tried to improve students' pronunciation and listening skill by using songs, in order to be able to use the English properly, and also change the pattern of their learning instead of their hobby that can add their knowledge or enjoy a hobby while studying and also I tried to investigate whether students' pronunciation and listening skill could be improved by using songs. It is hoped that the students' pronunciation and listening skill can be improved.

The purposes of this research are to explain the process of teaching listening and pronunciation by using songs and to find out whether the use of songs can help to Improve the Students' pronunciation and listening English words or not. 


\section{METHOD}

The research was carried out at English Education Department. The instructional process was done in two month. This study was conducted for two months, from February10 2016 to March $30^{\text {th }} 2016$. It is including the preresearch, action and activities of the action. After two months the writer wrote the thesis report. The research design used a Classroom Action Research (CAR), which is based on the writer's aim at improving students' pronunciation and listening skill by using songs. Kemmis and Mc. Taggart (1988) explain that action research is a group of activity and a piece of descriptive. The models and exresearch carried out by the teacher in his or her own classroom, without the involvement of others, which is aimed at interesting our understanding rather than changing the phenomenon under the investigation that would not be considered by these commentators to be 'action research'. The essential impetus for carrying out action research is to change the system. The models and explanationsforeach stepare asfollows:

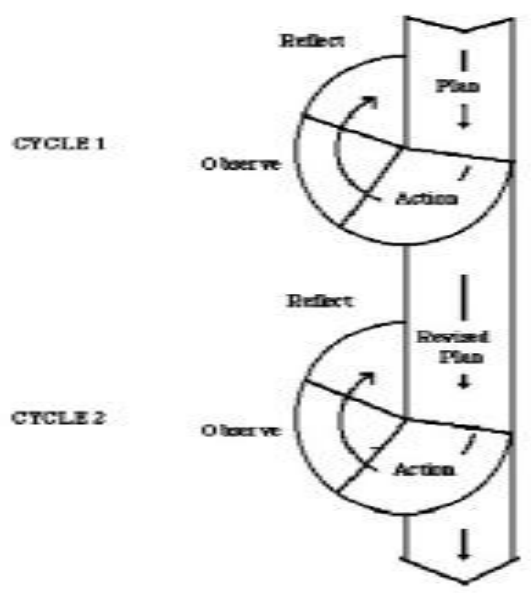

Figure 1 The Action Research Spiral (based on Kemmis and Taggart 1988:14)

This study was analyzed by qualitative and quantitative data. The data for qualitative were described through the observation and field notes explaining about the process or situation during the teaching and learning process. Quantitative data are analyzedby using the formula: 
$M=\frac{\sum X}{N}$

Adapted by Hatch and Hossein (1982)

Where:

$\mathrm{M}=$ Mean score

$\sum X=$ The Sum of Total Score

$\mathrm{N}=$ The Total Number of the Students

The formula used in analyzing the percentage students' achievement (Arikunto, 2010:264).

$P=\frac{\sum \text { The Frequency of correct answer }}{\sum \text { The Total Number of the Students }} \times 100 \%$

\section{FINDINGS AND DISCUSSION}

Having analyzed the data, to answer the first research question how the use of songs to improve the students' pronunciation and listening skill. The using of songs was indicated well from the beginning of the first cycle till the second cycle so it was obvious that the use of songs was effective to improve the students' pronunciation and listening skill. The improvement of students' pronunciation and listening skill could happen by using songs. Type of activities as follow: Questions and answers related to the songs, focus listen the songs, focus to recognize the pronunciation, individual work, oral practice, and evaluation of learning. Actually, students' pronunciation and listening skill could not be perfect because there were all influenced by their own dialect for pronunciation and Indonesian is different with English so it is difficult to recognize what they listen and to improving their listening skill. In this case training it means training our listener, if we always training our listener unfortunately we also improve our listening skill and in training listening English words by using songs we can recognize the English words, and when we have recognized the English words it can help to improve our listening skill.It is recommended, the use of songs which are simple, enjoyable, pleasurable, comfortable, and easy to learn. 


\section{Songs and Listening}

Based on the results of the analysis of the data found that the use of songs in the teaching and learning process, and to answer second question can the use of songs improve students'pronunciation and listening skill. The first, it can be explained that the action research was successfulbecause what have been implemented before in accordance with what was in the plan of action. Most importantly,student learning outcomes in the second cycle in creased from the first cycle,where in listening the number of students who achieve a minimum score of 65 were 7 students, and which reached a maximum value of 60 were 16 students. For the second cycle, in listening the number of students achieving a minimum value of 65 amounts to 6 students and that reached a maximum value of 65 were 17 students and in pronunciation the number of students achieving a minimum valueof 65 amounts to 4 students and that reached a maximum value of 65 were 19 students. Although in second cycle did not achieve 100\% value of 65 , there are 6 students did not achieve value of 65 it can see in table 4.2.1 and the 6 students are the same students did not achieve value of 65 in first cycle. The effect is attendance by the students, in first cycle some of them just follow the first meeting and last meeting was followed as well as in second cycle.

In accordance with the measurement of achievement criteria, the first in listening research activities of this Class action can besaid to besuccessful, ifat least $69.56 \%$ of thetotal number of students in the class reaches a minimum value of 65 , and the results obtained for the first cycle to $30,43 \%$ of the total number of students declared successful. In this case, it obtained a minimum value of 60 and $69,56 \%$ declared not succeeded. Whereas forthe second cycle $73.91 \%$ of the total number of students declared successful and $26.08 \%$ stated not succeed. The table below summarized all the scores since first cycle to second cycle.

Table 4.3.1 The performance of all the students' scores

\begin{tabular}{|c|c|c|cc|}
\hline Number & STUDENTS & $\begin{array}{l}\text { LISTENING POST } \\
\text { TEST CYCLE 1 }\end{array}$ & $\begin{array}{l}\text { LISTENING } \\
\text { CYCLE 2 }\end{array}$ & POST TEST \\
\hline 1 & A & 100 & 70 \\
\hline 2 & B & 40 & 70 \\
\hline
\end{tabular}




\begin{tabular}{|c|c|c|c|}
\hline 3 & C & 50 & 90 \\
\hline 4 & $\mathrm{D}$ & 80 & 70 \\
\hline 5 & $E$ & 0 & 55 \\
\hline 6 & $\mathrm{~F}$ & 50 & 60 \\
\hline 7 & $\mathrm{G}$ & 100 & 80 \\
\hline 8 & $\mathrm{H}$ & 60 & 80 \\
\hline 9 & I & 80 & 75 \\
\hline 10 & $\mathrm{~J}$ & 80 & 95 \\
\hline 11 & $\mathrm{~K}$ & 100 & 90 \\
\hline 12 & $\mathrm{~L}$ & 80 & 70 \\
\hline 13 & $M$ & 60 & 75 \\
\hline 14 & $\mathrm{~N}$ & 10 & 65 \\
\hline 15 & $\mathrm{O}$ & 20 & 60 \\
\hline 16 & $\mathrm{P}$ & 0 & 10 \\
\hline 17 & Q & 30 & 65 \\
\hline 18 & $\mathrm{R}$ & 50 & 80 \\
\hline 19 & $\mathrm{~S}$ & 10 & 65 \\
\hline 20 & $\mathrm{~T}$ & 40 & 90 \\
\hline 21 & $\mathrm{U}$ & 50 & 60 \\
\hline 22 & V & 0 & 55 \\
\hline 23 & W & 40 & 65 \\
\hline & Total & 1130 & 1595 \\
\hline & Mean & 49.13 & 69.34 \\
\hline
\end{tabular}

Thus, it is clear that there is an improvement after the implementation the use of songs at the first-cycle to the second cycle. The improvement is increased by $43.48 \%$ (the first cycle $30.43 \%-73.91 \%$ at the second cycle). It is pictured in Table 4.4.1 below:

Table 4.4.1 Increase Percentage Data in Listening Learning Outcomes 


\begin{tabular}{|l|l|l|l|l|}
\hline Activities & $\begin{array}{l}\text { Numbe } \\
\text { r of }\end{array}$ & $\begin{array}{l}\text { The } \\
\text { number } \\
\text { student }\end{array}$ & $\begin{array}{l}\text { Success Percentage } \\
\text { of } \\
\text { Successf } \\
\text { ul } \\
\text { Students }\end{array}$ & $\begin{array}{l}\text { Percentage } \\
\text { increase in } \\
\text { listening } \\
\text { learning } \\
\text { outcomes }\end{array}$ \\
\hline Cycle 1 & 23 & 7 & $30.43 \%$ & $43.48 \%$ \\
\hline Cycle 2 & 23 & 17 & $73.91 \%$ & \\
\hline
\end{tabular}

\section{Songs and Pronunciation}

The second in pronunciation the number of students who achieve a minimum score of 65 were 9 students, and which reached a maximum value of 60 were 14 students, in pronunciation research activities of this Class action can besaid to be successful, if at least $60.86 \%$ of the total number of students in the class reaches a minimum value of 65 , and the results obtained for the first cycle to $39,13 \%$ of the total number of students declared successful. In this case, it obtained a minimum value of 60 and $69,56 \%$ declared not succeeded. Whereas for the second cycle $86.95 \%$ of the total number of students declared successful and $13.05 \%$ stated not succeed. The table below summarized all the scores since first cycle to second cycle.

Table 4.3.2 The performance of all the students' scores

\begin{tabular}{|c|c|c|c|}
\hline Number & STUDENTS & \begin{tabular}{l}
\multicolumn{2}{l}{ PRONUNCIA } \\
TION POST \\
TEST CYCLE \\
1
\end{tabular} & $\begin{array}{l}\text { PRONUNCIATION } \\
\text { POST TEST CYCLE } \\
2\end{array}$ \\
\hline 1 & A & 100 & 80 \\
\hline 2 & B & 80 & 80 \\
\hline 3 & $\mathrm{C}$ & 50 & 95 \\
\hline 4 & $\mathrm{D}$ & 100 & 85 \\
\hline
\end{tabular}




\begin{tabular}{|c|c|c|c|}
\hline 5 & E & 40 & 55 \\
\hline 6 & $\mathrm{~F}$ & 50 & 65 \\
\hline 7 & $\bar{G}$ & 80 & 80 \\
\hline 8 & $\mathrm{H}$ & 80 & 80 \\
\hline 9 & I & 100 & 75 \\
\hline 10 & $\mathrm{~J}$ & 100 & 95 \\
\hline 11 & $\mathrm{~K}$ & 60 & 95 \\
\hline 12 & $\mathrm{~L}$ & 100 & 75 \\
\hline 13 & $\mathrm{M}$ & 60 & 75 \\
\hline 14 & $\mathrm{~N}$ & 50 & 65 \\
\hline 15 & $\mathrm{O}$ & 40 & 70 \\
\hline 16 & $\bar{P}$ & 0 & 20 \\
\hline 17 & Q & 50 & 65 \\
\hline 18 & $\mathrm{R}$ & 50 & 90 \\
\hline 19 & $\mathrm{~S}$ & 30 & 65 \\
\hline 20 & $\mathrm{~T}$ & 40 & 90 \\
\hline 21 & $\mathrm{U}$ & 50 & 65 \\
\hline 22 & $\mathrm{~V}$ & 20 & 55 \\
\hline 23 & $\mathrm{~W}$ & 80 & 65 \\
\hline & Total & 1410 & 1685 \\
\hline & Mean & 61.30 & 73.26 \\
\hline
\end{tabular}

Thus, it is clear that there is an improvement after the implementation the use of songs at the first-cycle to the second cycle. The improvement is increased by $47.82 \%$ (the first cycle $39.13 \%-86.95 \%$ at the second cycle). It is pictured in Table 4.4.2 below:

Table 4.4.2 Increase Percentage Data in Pronunciation Learning Outcomes 


\begin{tabular}{|l|l|l|l|l|}
\hline Activities & $\begin{array}{l}\text { Number of } \\
\text { students }\end{array}$ & $\begin{array}{l}\text { The number } \\
\text { of Successful } \\
\text { Students }\end{array}$ & $\begin{array}{l}\text { Success } \\
\text { Percentage }\end{array}$ & $\begin{array}{l}\text { Percentage } \\
\text { increase in } \\
\text { pronunciation } \\
\text { learning } \\
\text { outcomes }\end{array}$ \\
\hline Cycle 1 & 23 & 9 & $39.13 \%$ & $47.82 \%$ \\
\hline Cycle 2 & 23 & 20 & $86.95 \%$ & \\
\hline
\end{tabular}

Although in second cycle did not achieve $100 \%$ value of 65 , there are 3 students did not achieve value of 65 it can see in table 4.2.2 and the 3 students are the same students did not achieve value of 65 in first cycle it can see in table 4.1.2. The effect is attendance by the students, in first cycle some of them just follow the first meeting and last meeting was followed as well as in second cycle.

Byusing the songs as media in teaching and learning process, the students can receive better improvement. In accordance with the theory of Albert Einstein: "Education is not learning of facts, but the training of the mind to think."

\section{Conclusion}

Based on the results of this research, the writer could make the conclusions as follows. First, there were improvements of the students' pronunciation and listening skill. Media is one of important things that must be used during the teaching and learning process in order to reach the purpose of teaching but also teacher have to be creative to manage the classroom procedure by using interesting activities so the students could interested, enjoyable, pleasurable, and comfortable, and easy to learned.

Second, the implementation of songs could improve Students' pronunciation and listening skill in second grade students of English Education Department. The improvement can be seen from the score of the students in the tests.There isan increase instudent learning outcomesof Intermediate listening 
subjects after using the songs in teaching and learning activities in which the conduct of research first cycle to second cycle results increased by $43.48 \%$ in listening and $47.82 \%$ in pronunciation. In Listening, the improvement in the results of this study can be seen from the average values obtained from post tests and evaluation activities in three meetings and learning activities for cycle one until cycle two. In the first cycle of the 23 students, 7 students achieved an average score of at least 60 or $30.43 \%$ of the total number of students declared successful, and the second cyclehas increased, whichof the 23 students 17 students can achieve average of at least 65 or 73,91\% and the number of students declared successful and in pronunciation, the improvement in the results of this study can be seen from the average values obtained from post tests and evaluation activities three meetings and learning activities for cycle one until cycle two. In the first cycle of the 23 students, 9 students achieved an average score of at least 60 or $39.13 \%$ of the total number of students declared successful, and the second cycle has increased, which of the 23 students 20 students can achieve average of at least 65 or $86,95 \%$ and the number of students declared successful. The writer concluded that the use of songs could help the students to get involved in teaching and learning process because there were new atmosphere and enjoyable in the teaching and learning process. And also the students automatically could help each other in improving pronunciation and listening skill.

\section{REFERENCES}

Arikunto, S. (2010).Prosedur penelitian :Suatu Pendekatan Praktik. (Edisi Revisi).Jakarta : Rineka Cipta

Hatch and Hossein.(1982).Research Design and Statistics for Applied Linguistics.University of California, Los Angels.New Burry House Publishers, Inc.

Kemmis, S. and R McTaggart.(1988). Action Research -some ideas from The Action Research Planner, Third edition, ed. Deakin University.

Morley, J. (1994). Pronunciation pedagogy and theory: New views, new directions. Alexandria VA: TESOL 
Vandergrift, L. (n.d.). Theory and practice in Modern Foreign Language Competence. Retrieved 2002, from

http://www.llas.ac.uk./resources/goodpractice.aspx?resourceid=67

Willing, K. (1989). Teaching How to Learn. Sydney: NCELTR. 